\title{
SEPT5 Gene
}

National Cancer Institute

\section{Source}

National Cancer Institute. SEPT5 Gene. NCI Thesaurus. Code C97727.

This gene plays a role in cell division. 